Case research

\title{
Impact of asset quality on bank profitability - Case Study
}

\author{
Article history: \\ Received: 7 October 2015 \\ Sent for revision: 21 October 2015 \\ Received in revised form: 6 December 2015 \\ Accepted: 7 December 2015 \\ Available online: 30 December 2015
}

\begin{abstract}
The paper explores the impact of asset quality on banks' profitability in the case of a commercial bank in Serbia. Parameters covered as key indicators of the impact on profitability are: maturity of the portfolio, clients' ratings, NPL (Non-Performing) loans, effective coverage of the total portfolio with collaterals and effective coverage of NPL portfolio with collaterals. To test the influence of parameters on the dependent variables, we used the fixed effect regression model. The success of the model is monitored through Schwarz's Bayesian Criterion where the absolute number shows the success of the model - the lower the number, the better the model. The research results indicate the manner and intensity of the impact of the discussed parameters on the margins of profitability. Applied research model is also useful in analyzing the impact of asset quality on the profitability of other commercial banks. The scientific contribution of the research lies in the fact that it offers a new way of testing theoretical assumptions that emerged from adapting practical methods to the needs for making general conclusions and theoretical generalizations, based on which we create space for further scientific research and improvements in this area.
\end{abstract}

Keywords: asset quality, profitability of banks, NPL, contribution margin.

\section{Uticaj kvaliteta aktive na profitabilnost banke - studija slučaja}

Apstrakt: U radu je istraživan uticaj kvaliteta aktive na profitabilnost banke na primeru jedne poslovne banke u Srbiji. Parameti koji su obuhvaćeni kao

\footnotetext{
${ }^{1}$ Singidunum University, Faculty of Business in Belgrade, kasavicapet@yahoo.com

2 Singidunum University, The Faculty of Business, Belgrade
} 
Kasavica P., Jović Z.: Impact of asset quality on bank profitability - Case Study

ključni indikatori uticaja na profitabilnost su: ročnost portfolija, rejting klijenata, NPL (Neperformisani) krediti, efektivna pokrivenost ukupnog portfolija instrumentima obezbeđenja i efektivna pokrivenost NPL portfolija instrumentima obezbeđenja. Za testiranje uticaja parametara na zavisne varijable korišćen je fixed effect model regresije. Uspešnost modela je praćen preko Schwarz's Bayesian Criterion čiji apsolutan broj pokazuje uspešnost modela, što je niži broj, to je model bolji. Rezultati istraživanja ukazuju na način $i$ intenzitet uticaja analiziranih parametara na margine profitabilnosti. Primenjeni model istraživanja je upotrebljiv pri analizi uticaja kvaliteta aktive na profitabilnost i drugih poslovnih banaka. Naučni doprinos istraživanja leži u činjenici da je ponuđen nov način testiranja teorijskih postavki koji je proistekao iz procesa prilagođavanja praktičnih metoda potrebama izvođenja generalnih zaključaka i teorijskih uopštavanja, na osnovu kojih se stvara prostor za dalja naučna istraživanja i unapređenja u ovoj oblasti.

Ključne reči: kvalitet aktive, profitabilnost banke, NPL, kontribuciona margina,

\section{Introduction}

Profitability of banks is interpreted on the basis of two key indicators, the indicators of ROE (return on equity) and ROA (return on assets). ROE (net profit after tax/equity capital) is the most important indicator, because it shows the bank's shareholders the amount of profit they can expect on the basis of book value of the capital they invested in a particular bank. ROA (net profit after taxes/total assets) shows the level of bank's effectiveness in the management of assets quality. This indicator is most trusted among regulatory bodies, the central banks and rating agencies. In its calculation it is recommended to use the average amount of assets during the year, due to seasonality present in banking business. Through a practical example, this paper will highlight the present problem in the analysis of the impact of asset quality on bank's profitability.

The aim of this study is to use a practical example to show the effect of asset quality on the profitability of commercial banks and quantify this impact through a concrete research. The importance of this research lies in the confirmation of theoretical assumptions and the fact that it is providing a specific practical tool for calculating the asset quality parameters and profitability of any commercial bank that has an interest in implementing this type of analysis. The originality of the research lies in the specific compilation of modern methods for the assessment of banks' profitability elements, used by first-class banks, and also in the statistical methods for verifying the accuracy of inference on small samples. The scientific contribution of the research lies in the fact that it offers a new way of testing theoretical 
Kasavica P., Jović Z.: Impact of asset quality on bank profitability - Case Study

assumptions that emerged from adapting practical methods to the needs for making general conclusions and theoretical generalizations, based on which we create space for further scientific research and improvements in this area.

The study presents the analysis of the relationship between the quality of assets (loans in the Master Bank micro segment: A bank which operates in the Serbian market. Due to preservation of confidentiality of internal data, it is not possible to specify the real name of the institution.) and profitability of the commercial bank. Within this analysis, we pointed out the influence of 5 variables, i.e. 5 parameters that characterize the quality of assets in a commercial bank, on the parameters of bank profitability. The 5 parameters are: maturity portfolio, clients' ratings, NPL loans, the effective coverage of the total portfolio with collaterals, as well as effective coverage of NPL portfolio with collaterals. The covered period is a period of 4 years, i.e. the period 2011 - 2014.

In accordance with a defined purpose and subject of the research, this paper will test the following research hypotheses:

- HO: Asset quality has a decisive influence on the profitability of banks.

- $\mathrm{H} 1$ : Key categories of asset quality that serve as indicators of the impact on profitability are: maturity portfolio, clients' ratings, NPL loans, the effective coverage of the total portfolio by collaterals, as well as the effective coverage of the NPL portfolio by collaterals.

\section{Literature review}

Diversifying funding sources and diversifying the banking portfolio aims to reduce the risks of bank placements, while at the same time analyzing whether the required capital adequacy ratios make the banks secure enough and if they are, to some extent, giving them the sense of false security (Miller $\&$ VanHose, 1993). Limitations of assets, regulatory requirements relating to banks' capital and the necessity of prudential supervision (Mishkin, 2004), demand the necessity of asset and liability management in banks, as well as measurement and assessment of the banking business (Rose, 1999). One of the main goals of banks' functioning is to ensure profitability. Hence the importance of designing profitability and mastering the profitability factors of banks' and banks' financial indicators. (Ćirović, 2007). Certain studies reveal determinants of bank asset quality and banks' profitability, and in particular the impact of NPLs on the profitability of banks in developing countries (Swamy, 2015). We also used dynamic panel data methods for testing the determinants of non-performing loans (NPLs) in the Greek banking sector, separately for each category of loans such as consumer loans, business loans and mortgage loans, in order to show that both macroeconomic factors 
and specific factors of individual banks may have an impact on credit quality and that these effects vary among different categories of loans (Louzis, Vouldis \& Metaxas, 2010). We also investigated specific determinants that affect the quality of the loan at the macroeconomic level and at the level of banking sector and individual banks. This research of NPLS in Central, Eastern and Southeastern Europe (CESEE) in the period of 1998-2011 also attributed the level of NPLs both to macroeconomic conditions and to specific factors of individual banks. The level of NPLs depends on macroeconomic conditions, such as GDP growth, unemployment, inflation, etc., and the analysis also indicates that there are strong feedback effects from the banking system on the real economy, which is evident in many CESEE countries that faced high levels of NPLs which negatively affect the pace of economic recovery (Klein, 2013). Identifying the main determinants of banking assets quality in a weak banking environment, in the case of Nigeria in the period 2004 - 2008, reveals that the deterioration in asset quality in the Nigerian banking industry is associated with the syndrome of excess liquidity and relatively large capital base, which encourages reckless borrowing from banks and increases the level of unsafe loans in banks' portfolios (Ezeoha, 2011).

The impact of capital ratios on banks' profitability, in light of the economic cycle, is analyzed using data from the US banking sector, involving several economic cycles since the late 1970s until the recent financial crisis from 2008 to 2010 (Osborne, Fuertes \& Milne, 2012).

We investigated whether banks with more risky loans and greater exposure to interest rates make the selection of active and passive interest rates to achieve higher net interest margins. The research results of different bank classes, depending on the size of the banks, for the period 1989-1993, show that the net interest margin of commercial banks reflects the risk of loan default and the premium for interest rates risk. Net interest margins of the largest banks are affected by the risk of default (non-return) obligations, but not the interest rate risk, which is consistent with a higher concentration of their investments in a diversified portfolio of securities and off-balance hedging instruments. In contrast, regional banks are sensitive to interest rate risk, but not to the risk of non-repayment of money (default risk). Data show that off-balance hedging instruments promote more diversified and more profitable investments than deposit and capital financing, and that the differences between these classes of banks in the risk of interest rates changes and the liquidity risk, are actually associated to the differences in exposure to off-balance hedging instruments (Angbazo, 1997).

The study, which attempts to identify the key determinants of profitability of state (Public Sector Banks) banks in India, is based on the model of multivariate regression analysis that uses time data in the interval 1991-2004. This study shows that variables such as non-interest income, operating 
expenses, commissions, fees and spreads have a significant connection with total net profits of the analyzed banks (Bodle \& Verma, 2007). The influence of investment funds of commercial banks on banking risks and profitability of banks (Gallo APILADOR \& Kolari, 1996) was considered, as well as the determinants of bank profitability in the case of Spain and share of NPLs in total loan portfolio (Trujillo-Ponce, 2015). Comparative analysis of NPLs in the banking system of Serbia, Croatia and Macedonia, shows the differences in the quality of the loan portfolio in the sampled countries and the reasons for these differences. The level of NPLs and their relation compared to total loans is important for the economic development of these countries, through the influence of credit activity on consumption and capital adequacy ratios that limit the potential for growth. Creation of a spiral is evident here, as a higher credit default (NPL) creates the low economic growth and low growth creates additional credit default, i.e. additional NPL portfolio (Jolevski \& Andovski, 2015).

The issue of NPLs is considered from various angles: the introduction of technical standards of supervisory reporting and non-functional exposure (EBA, 2013); which is important for NPL's, apart from the economic cycles (ECB, 2013); the NPL in the GCC countries and their macroeconomic impact (Espinosa \& Prasad, 2010); the level of NPLs in the records of some significant banks (Hou \& Dickinson, 2007).

Non-performing loans (NPLs) were the immediate cause of the rapid spread of systematic risk in the banking and overall financial sector in Serbia. In order to measure the propagation of systematic risk within the financial system, this paper uses a new systematic indicator - infection of the financial sector with non-performing loans (NPL proportional share in the assets of the financial sector with NPL / AFS), while for the assessment of systematic risk potential spill over to the real sector, the authors have also used a new synthetic indicator - macroeconomic contagion with non-performing loans (NPL expressed as a percentage of GDP - NPL / GDP) (Vuković \& Domazet, 2013).

Determinants of bank profitability are analyzed on the example of top five largest banking holding companies in the United States, measured by total assets. The study develops an appropriate econometric model that explores the basic determinants of profitability for the analyzed bank holding companies. The econometric model is based on the internal aspects of the observed bank holding companies, such as ROA, and the impacts of various environment aspects measured by GDP growth and developed based on the guidelines given by the economists and the banking industry (Scott \& Arias, 2011).

At the very beginning of the financial and economic crisis in 2008, the Serbian banking sector achieved a positive net pre-tax result, what was by even 48 , 
Kasavica P., Jović Z.: Impact of asset quality on bank profitability - Case Study

9\% higher profit than in 2007. Spill over effects of the global economic crisis on Serbian banking sector were transmitted in 2009, when the net pre-tax result declined by even $42,7 \%$. In first line, it was a result of an increase of expenses for indirect write-offs of loans, investments and provisions. One of the most important factors contributing to high amounts of net losses of commercial banks in the previous period includes an increase of net operating expenses, especially expenses on account of a write-off of uncollected claims (Miljković, Filipović \& Tanasković, 2013).

\section{Materials and methods}

Below given is the CM model (Contribution margin) of Master bank (Table 1). It is the model of different levels of profit margins ranging from CM1 to CM6.

Table 1. Master bank profitability according to different levels and profit margins

\begin{tabular}{|c|c|c|}
\hline Single deal & Profit centre & Business line \\
\hline average assets & average assets & average assets \\
\hline average liabilities & average liabilities & average liabilities \\
\hline contribution margin assets & contribution margin assets & contribution margin assets \\
\hline \multirow[t]{3}{*}{ contribution margin liabilities } & contribution margin liabilities & contribution margin liabilities \\
\hline & bid/ask spread & bid/ask spread \\
\hline & & transformation margin \\
\hline CM1 & CM1 & CM1 (Gross NII) \\
\hline standard risk cots & standard risk cots & standard risk cots \\
\hline deposit insurance & deposit insurance & deposit insurance \\
\hline CM1a & CM1a & CM1a (Net NII) \\
\hline fee \& commission income & fee \& commission income & fee \& commission income \\
\hline trading income & trading income & trading income \\
\hline other operating result & other operating result & other operating result \\
\hline CM2 & CM2 & CM2 (Net revenues) \\
\hline cost of capital & cost of capital & cost of capital \\
\hline CM3 & CM3 & CM3 (Risk adj. Net revenues) \\
\hline \multirow[t]{6}{*}{ product costs } & direct costs & direct costs \\
\hline & indirect costs & indirect costs \\
\hline & product costs & product costs \\
\hline & product costs discharge & product costs discharge \\
\hline & & general overhead \\
\hline & & cost compensation \\
\hline CM4 & CM4 & CM4 (EVA minus SRC) \\
\hline $\begin{array}{l}\text { diff. standard vs. actual risk } \\
\text { costs }\end{array}$ & $\begin{array}{l}\text { diff. standard vs. actual risk } \\
\text { costs }\end{array}$ & $\begin{array}{l}\text { diff. standard vs. actual risk } \\
\text { costs }\end{array}$ \\
\hline \multirow[t]{2}{*}{ CM5 } & CM5 & CM5 (EVA) \\
\hline & & cancellation cost of capital \\
\hline \multirow[t]{3}{*}{ CM5a } & CM5a & CM5a (Pre-tax profit) \\
\hline & & $\operatorname{tax}$ \\
\hline & & minorities \\
\hline CM6 & CM6 & CM6 (Net profit) \\
\hline
\end{tabular}

Source: internal survey of the Master bank 
The relevant margins are calculated to create a unique tool to measure and manage the performance, all in order to create a uniform basis for making decisions on the level of commercial banks. Margin calculations are performed at different levels, depending on the needs of future interpreters and users of these results, as well as the objectives of the analysis. In this regard, the calculation of margins itself is performed per client, per team, i.e. portfolio of the specific credit officer, profit centre, business line, and also for the overall portfolio. Also, it must be noted that the profitability of the specific credit arrangement is made on the basis of different models of pricing tools that offer the possibility of calculating the ROE indicators, which, depending on the bank's policy, should not be lower than a certain threshold value. The subject tools take into account the parameters of arrangement prices, rating of the borrower, product type and maturity, collateral, etc.

Below given is a description, i.e. content of individual contribution margins.

\section{- Contribution margin CM1}

The basis of the subject margin calculation is the contribution margin of assets and liabilities. Essentially, it is about the relationship between the interest income per credit operation and expenditure in terms of prices of loan funding sources, as well as the expenditures for interest on deposits and the cost of financing sources for deposits. A part of the subject margin calculation is also the transformational margins arising from currency or maturity mismatches. These are: maturity transform margin and currency transform margin. The higher the maturity congruence of assets and liabilities, the lower the liquidity risk and vice versa. On the other hand, the higher the currency congruence, the higher the amortization of the exchange rate changes risk and vice versa. The mismatch of assets and liabilities not only increases the subject risks, but leads to a decline in profitability. A part of the calculation of subject margins is also the so called bid/ask spread which is the difference in interest rates between the placement and collecting funds. Ask price is the price at which the bank sells the assets, while the bid price is the price at which the bank collects the funds. In these transactions, the bank raises or lowers the middle transfer price that represents the middle market interest rate. It must be noted that this depends on the type of interest rate, i.e. whether it is a fixed, variable or administrative rate. The variable rate is dependent on changes in the reference rate (e.g. Euribor), while for the fixed rate; the conditions relating to the product do not change at least for one year. Administrative rate is the rate for which the conditions related to a specific product may change at any time.

\section{- Contribution margin CM1a}

A part of the contribution margin CM1a calculation is the contribution margin $\mathrm{CM} 1$ which is reduced by the parameters of standard risk costs (SRC) and 
Kasavica P., Jović Z.: Impact of asset quality on bank profitability - Case Study

deposit insurance costs. Standard risk costs should cover the expected loss resulting from the implementation of credit risk, i.e. the risk that the borrower will not repay the loan according to the terms of the loan agreement. The principle is based on the fact that all healthy clients should cover the loss of customers in default through the standard risk cost - provisioning.

The activity of the credit institution is resulting in credit exposure towards the contract party, the beneficiary, i.e. the risk that all or part of the amount that is expected from the beneficiary will not be repaid. On the other hand, each credit exposure carries the probability to generate losses until maturity deadline. The losses generated by the portfolio may be interpreted as bank costs. On the other hand, provisions for covering the risk are the expected losses of the portfolio, estimated based on current information that characterize the same portfolio. The actual risk costs (ARC) are a part of, or fraction, of the provisions for covering the risks relating to total loans during the average period of validity. The actual risk costs (provision) can be different due to the economic cycle, the effects of portfolio maturity, and other factors. In other words, they are actually present costs incurred over time, covered in income statement, consisting of: the allocation of costs arising from new loans and deterioration of the existing portfolio rating, as well as the release of certain costs (collection of the existing exposure, improving the rating of the existing portfolio i.e. clients), as well as direct write-offs by charging or writing off non-performing NPLs.

Similar to other types of costs, these costs will vary over time. Variations are primarily guided by the economic cycle, but also by other aspects. Also, they can vary considerably according to acute cases of bankruptcy or liquidation of one or several large credit placements. Also, they are conditioned by the risk appetite of the specific institution (smaller or larger risk appetite, approval process, etc.). As a result of the presented variability of these costs, and in order to adequately determine the price of new placements which have to cover the anticipated losses, the category of standard risk costs (SRC) provision, is introduced. Standard risk costs are normally calculated on the basis of historical data and represent long-term average real costs of the institution. They vary the same as the actual costs, but depend on the allocation of new loans, deterioration of rating of existing clients, as well as on the exemptions coming from improving the rating. Direct write-offs are not included in the calculation of standard risk costs - provisions.

Standard risk costs are calculated on a "live" part of the portfolio and concern only the loans which are not NPLs. Calculation is performed monthly for an existing job, during the arrangement period. The calculated SRC changes monthly based on the actual risk profile of exposure (based on the current rating). 
Kasavica P., Jović Z.: Impact of asset quality on bank profitability - Case Study

Figure 1. Client interest rate and cost elements in banking calculation

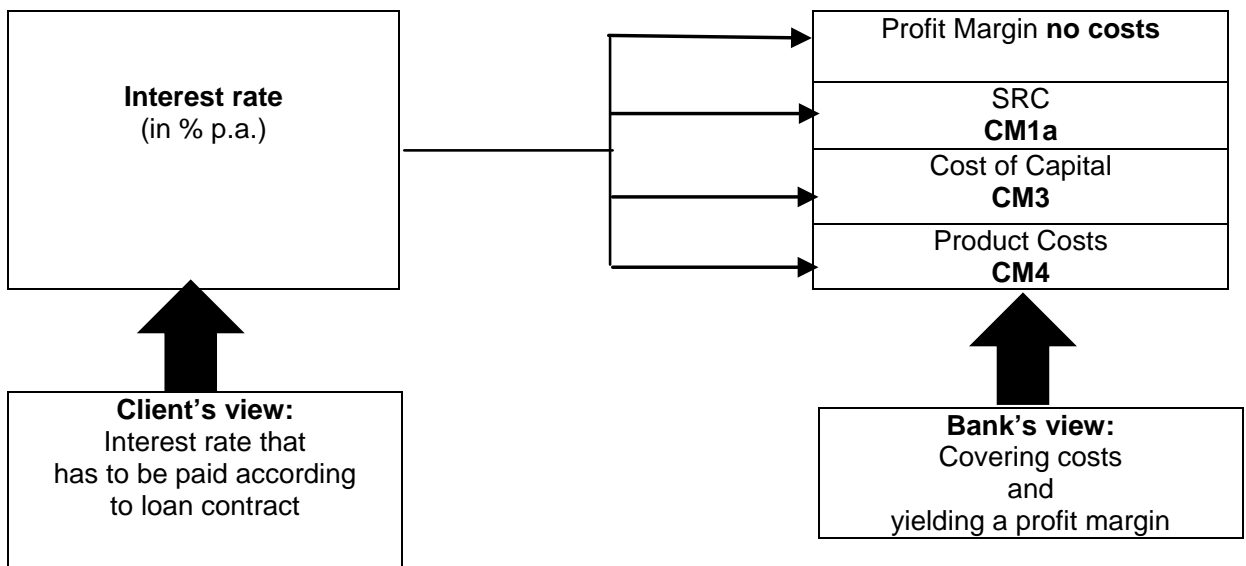

Source: authors' survey

Standard Risk Costs (SRC) are accounted in the contribution margin CM1a (Fig. 1). They are charged for asset side products and decrease the net interest income by a determined cost considering the credit risk.

Assume that SRC for one-period bullet payment is needed it can be expressed as follows:

SRC = PD $\times$ LGD / $1-P D$, where:

- $\quad P D$ is a default probability for one period

- LGD is a loss-given default, estimated according to the nature of single transaction (quality of security instrument, average age of accounts receivable, subordination of debt, etc.)

- 1-PD is the selection of non-defaulted clients from the granted production able to settle exposure with the bank during the period of estimation

The multiple period SRC is calculated exactly on the same basic principle as in case of single period SRC. It means that sum of all interest revenues collected has to cover all losses generated over the lifetime. It may be expressed by equation:

$\sum_{t}$ Revenues $t=\sum_{t}$ Losses $t$

where $t$ is time from origination until maturity/re-pricing moment. This equation may be rewritten and expressed in following manner: 


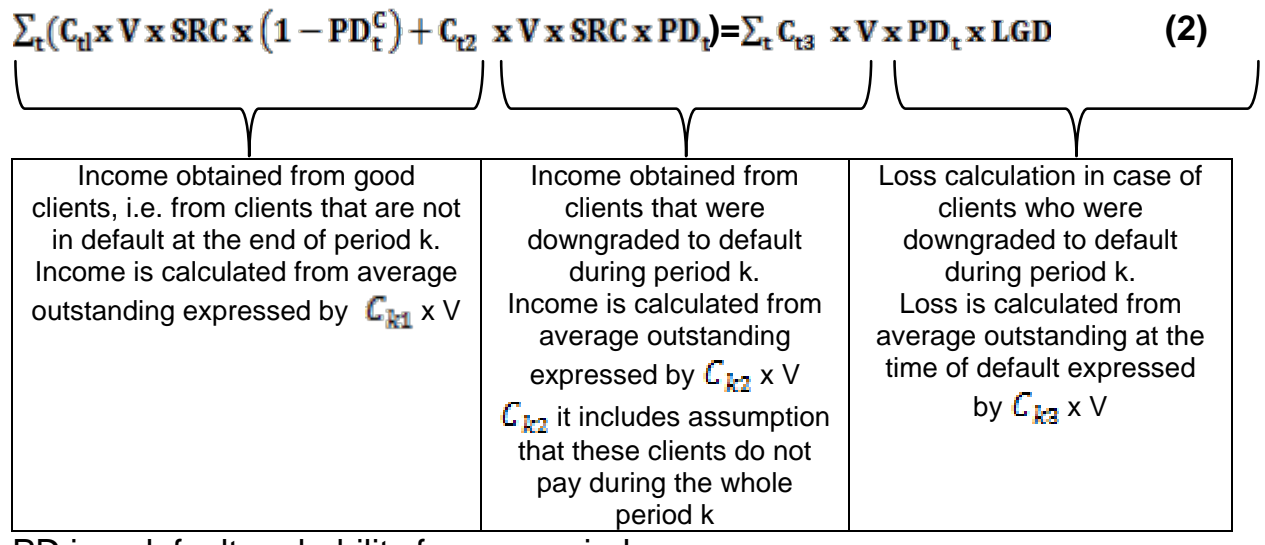

PD is a default probability for one period

LGD is a loss-given default, estimated according to the nature of single transaction (quality of security instrument, average age of accounts receivable, subordination of debt, etc.)

Moreover, SRC is fixed till maturity. Therefore the equation may be rewritten as:

$$
\mathrm{SRC} \times \sum_{t}\left(C_{t l} x V \times\left(1-P D_{t}^{C}\right)+C_{t 2} \times V \times P D_{t}\right)=\sum_{t} C_{t 3} \times V \times P D_{t} \times L G D
$$

Considering previous equation, SRC can be expressed as:

$$
\mathrm{SRC}=\frac{\sum_{t} C_{t 3} x V \times P D_{t} x L G D}{\sum_{t}\left(C_{t l^{1}} x \boldsymbol{V}\left(1-P D_{t}^{C}\right)+C_{t 2} \times V \times P D_{t}\right)}=\frac{\sum_{t} C_{t 3} x V \times P D_{t} x L G D}{\sum_{t}\left(C_{t l^{x}}\left(1-P D_{t}^{C}\right)+C_{t 2} \times P D_{t}\right)}
$$

$P D^{C}$ is cumulative probability of default. It measures the portion of clients/accounts in default (in \%) from the origination till end of certain period, e.g. till period $\mathrm{k}$ (denote $P D_{K}^{C}$ ). Then, $\left(1-P D_{K}^{C}\right.$ ) denotes all good (nondefaulted) clients that are able to pay till end of period k. It $\left(1-P D_{K}^{C}\right)$ can be also expressed as:

$$
\left(1-P D_{K}^{C}\right)=\left(1-P D_{1}\right) \times\left(1-P D_{2}\right) \ldots \ldots . .\left(1-P D_{K}\right)
$$

Let's assume that there is only one period over the lifetime of the deal. Denote average outstanding of defaulted clients $\mathrm{Ct} 3 \times \mathrm{V}$ as $\mathrm{Vd}$, average outstanding of non-defaulted clients Ct1 $\times \mathrm{V}$ as $\mathrm{Vnd}$ and $\mathrm{Ct} 2$ as $\mathrm{k}$, then the formula may be rewritten into formula for single period:

$\mathrm{SRC}=\frac{\sum_{1} V_{D} x P D_{1} \times L G D}{\sum_{1}\left(V_{N D} x\left(1-P D_{1}^{C}\right)+k x V \times P D_{1}\right)}=\frac{V_{D} \times P D x L G D}{V_{N D} x(1-P D)+k x V_{N D} x P D}$ 
These formulas show the degree to which costs and revenues can be projected either for one-period, bullet transactions or those of long-term maturities encompassing multiple repayments / instalments. Apart from this, they show the degree to which projected revenues cover projected costs of single transaction. This relation is described by SRC, which value is fixed during the time of concrete transaction and therefore has to be adequately and precisely determined. This is important in order to prevent his value from rocketing and jeopardizing profitability of long-term loan arrangements. The value of SRC is included in the interest rate to be charged to client. It is certain that SRC is higher in case it is evident that projected costs are or will be rising more than projected revenues.

PD and LGD are cost categories based on historical trend of concrete transaction to which analysed arrangement belongs. Additionally, they are based on the height of provisions, costs of capital and other parameters conditioned by the structure and the nature of transaction. Consequently, it is evident that cost categories will depend mostly on the quality of bank's total assets, or more precisely on their historical trend. What is most important about historical trend is the number of clients falling into NPL category, how many of them are late in payments and what are their overdue days, whether delays deteriorate external rating with the National Bank of Serbia, what is coverage ratio, i.e. effective coverage of concrete transaction.

On the other side projection of revenues is based on both concrete loan arrangement and historical trend of revenues generated by the whole range of similar transactions of sufficient quality to cover projected costs. It is the quality of assets that indicates how much income is generated from previous period and how high-quality clients and high-quality transactions can contribute to covering losses of executed and intended loan transactions.

Therefore, it is evident that SRC portraits relation between assets quality and costs of future arrangements. In addition it reveals potentials of acquisition of new clients in shaping future assets quality. Assets quality which conditions SRC, defines cost aspect and burdens profitability margins impacting directly the height of interest rate margins and competitive position of the bank. Worsened assets bring difficulties to acquisition of new clients as they increase the price of loan arrangements. On the other side, this may attract clients of a poorer credit-worthiness and potential transactions, as they are less sensitive to higher prices of loan arrangements in relation to high-quality clients and transactions.

\section{- Contribution margin CM2}

Contribution margin CM2 includes net income from fees and commissions. These fees are as follows: 
- Loan fees ((one-off (processing) fee, fee for unutilized funds under the revolving loan, overdraft, limit, early repayment fee, etc.).

- fees for payment operations

- fees for guarantees and letters of credit

- fees from card operations related to legal entities

Also, the calculation includes the net trading result (exchange operations), tied to a specific client or specific portfolio. In addition to the subject categories, the calculation includes other operating revenues, as well as the expenses.

\section{- Contribution margin $\mathrm{CM} 3$}

Contribution margin $\mathrm{CM} 3$ includes also the cost of capital. The cost of equity is the residual profit that remains for the bank's shareholders after satisfying all other stakeholders (employees, tax authorities). Also, it represents the amount by which the investors should increase the invested capital, to earn the same amount as when funding risk free investments. Methodological steps of calculating the cost of capital include:

- allocation of equity capital from the level of the entire bank towards the business lines

- calculation of the cost of capital within the business lines (cost of capital should cover: credit risk, market risk, operational risk)

- calculation of the cost of capital at the level of individual arrangement includes a simplified calculation of the business line without capital allocation at this level and takes into account only the credit risk.

\section{- Contribution margin CM4}

Contribution margin CM4 includes direct and indirect costs, which include the following types: personal, dependent on the staff, buildings, other, IT, current operations, marketing and legal costs. Then, the calculation includes the costs of business structures, which are costs that are allocated and related to business lines, but cannot be allocated to the products of the bank, transactions, etc. (sales support, marketing directed to customers population, economy, etc.). General expenses should also be mentioned, which are allocated to business lines (not lower than that), but related to organizational units that provide services to the entire commercial bank (management, internal audit, accounting, etc.). Then, the calculation includes the costs of products. Cost of products includes the costs that are allocated to the level of the product. These costs are calculated on the basis of the transaction price ((transaction price $=$ cost of front office + the cost of back office (or just the back office which is production-oriented, for example, the Loan Administration Department that creates the contracts and other documentation necessary for realization, then the Risk Management Department that considers connected risks of transactions, etc.)). 
Kasavica P., Jović Z.: Impact of asset quality on bank profitability - Case Study

\section{- Contribution margin CM5}

The category entering the calculation of CM5 margin is the difference between standard and actual risk costs (provisioning).

\section{- Contribution margin CM5a}

Includes the margin in which the costs of capital are cancelled.

\section{- Contribution margin CM6}

CM6 is the bank's profit after tax.

\section{Results and discusson}

Below given is the model of $\mathrm{CM}$ profitability of Master Bank in the field of Micro clients, which includes the movement of CM1 and CM5 margin in the period 2011-2014 (Table 2). Also, five individual categories of assets of Master Bank are stated, as well as the description of their impact on the margins of profitability.

A) Profitability of Master bank in the field of Micro clients

Table 2. The margins of profitability of Master Bank micro clients 2011-2014, in $000 \mathrm{RSD}$

\begin{tabular}{|c|c|c|c|c|}
\hline Margin/Year & 2011 & 2012 & 2013 & 2014 \\
\hline CM1 assets & 144,125 & 193,326 & 153,717 & 135,719 \\
\hline CM1 margin assets side & $4.99 \%$ & $6.92 \%$ & $5.87 \%$ & $5.85 \%$ \\
\hline CM5 & 62,206 & 434 & 137,059 & 73,611 \\
\hline CM5 margin & $2.15 \%$ & $0.02 \%$ & $5.23 \%$ & $3.17 \%$ \\
\hline
\end{tabular}

Source: internal survey of the Master Bank.

B) Parameters covered as key indicators of the impact on profitability are: maturity of the portfolio, clients' ratings, NPL loans, effective coverage of the total portfolio with collaterals and effective coverage of NPL portfolio with the collaterals. All the parameters are taken from analyzed case study of Master bank micro clients' portfolio (Table 1-7).

1. Maturity of the portfolio

Table 3. Master Bank micro clients' portfolio maturity 2011-2014, in 000 RSD (status, December of each fiscal year)

\begin{tabular}{|c|c|c|c|c|c|c|c|c|}
\hline Maturity/Y. & 2011 & $\%$ & 2012 & $\%$ & 2013 & $\%$ & 2014 & $\%$ \\
\hline Long term & $2,883,254$ & 91,3 & $2,814,675$ & 93,3 & $2,483,065$ & 88 & $2,786,462$ & 93,5 \\
\hline Short term & 274,746 & 8,7 & 200,160 & 6,7 & 336,143 & 12 & 192,252 & 6,5 \\
\hline Total & $3,158,000$ & 100 & $3,014,835$ & 100 & $2,819,208$ & 100 & $2,978,714$ & 100 \\
\hline
\end{tabular}

Source: internal survey of the Master Bank. 
Kasavica P., Jović Z.: Impact of asset quality on bank profitability - Case Study

As shown, Dinar loan amounts are divided by years, according to the deadline of 12 months (short) and over 12 months (long), as well as the percentage amount (Table 3). The maturity affects the aforementioned margins of profitability (Table 2), primarily by affecting the CM1 margin. The impact on the CM1 margin is due to the fact that, as a rule, long-term loans on annual level dictate a slightly lower interest rate, while in contrast, short-term loans dictate a somewhat higher level of interest rates. On the other hand, long-term resources are more expensive, and that in general reduces the profit margin within the relation between interest-source. In addition, the fee for processing the loan application is split evenly by periods of arrangement duration, which, as opposed to short-term loans, reduces the accounted fee in a particular year. This reduces the CM2 margin, but on the other hand, long-term loan arrangement is accompanied by mandatory additional products, such as the obligation of payment transactions, opening account for employees who receive salaries through the financing bank, etc. This affects the growth of fees for payment transactions during the year. Likewise, most commercial banks charge fees for non-performing the agreed turnover over bank account, so these fees are included in the subject calculation. Qualitatively speaking, the present long-term loans as a rule have a greater degree of effective coverage, clients have better ratings, and there is participation of the client in risk transactions, etc., which affects a certain reduction of provisions towards NBS (CM5), i.e. better rank of credit quality. On the other hand, the cost of capital according to the quality of the arrangement (CM3) is also lower. However, given the greater participation of other segments in the analysis of the loan application (legal department, collateral management department, risk management department, etc.), as well as in the preparation of documents for realization (loan administration, legal service, collateral management department), the product cost increases.

Table 4. Client rating and the amount of granted loans by ratings in $000 \mathrm{RSD}$ (Status, December of each fiscal year)

\begin{tabular}{|c|c|c|c|c|c|c|c|c|}
\hline Rating/Y. & 2011 & $\%$ & 2012 & $\%$ & 2013 & $\%$ & 2014 & $\%$ \\
\hline A & 766,752 & 24 & 833,405 & 25 & 674,611 & 24 & 720,026 & 24 \\
\hline B-C & 134,950 & 4 & 101,863 & 3 & 78,881 & 3 & 66,520 & 2 \\
\hline 1 & 0 & 0 & 0 & 0 & 0 & 0 & 1,667 & 0 \\
\hline $4-5$ & $1,048,458$ & 32 & $1,105,781$ & 33 & 797,266 & 28 & 955,091 & 32 \\
\hline $6-7$ & 582,240 & 18 & 487,425 & 14 & 444,797 & 16 & 447,641 & 15 \\
\hline 8 & 124,521 & 4 & 134,839 & 4 & 129,904 & 5 & 100,256 & 3 \\
\hline N & 0 & 0 & 0 & 0 & 0 & 0 & 88,625 & 3 \\
\hline R & 582,171 & 18 & 729,833 & 21 & 699,407 & 25 & 598,889 & 20 \\
\hline total & $3,241,103$ & 100 & $3,395,158$ & 100 & $2,826,879$ & 100 & $2,980,729$ & 100 \\
\hline
\end{tabular}

Source: internal survey of the Master Bank. 
It has to be pointed out that the key division is to internal ratings that range from $1-8$, and according to NBS there is a division into A, B, C, N, R (Table 4). From rating $A$ downwards, ratings are lined up from better to worse. The amount of loans by ratings affects the overall profitability, as poorer ratings, in addition to the initial higher interest rates, also bear the additional costs that reduce the CM5 margin. These costs are the costs of provisions towards the NBS. In addition to these costs, there are also costs of reserved capital by parent banks which are included in the calculation of CM3 margins. In short, a lower rating carries a higher cost, and therefore a higher level of loans under less favorable rating costs more and reduces the profits.

3. NPLs - loans overdue more than 90 days

Table 5. NPL, \% of the total portfolio (status with December of each fiscal year)

\begin{tabular}{|c|c|c|c|}
\hline 2011 & 2012 & 2013 & 2014 \\
\hline $15,40 \%$ & $11,70 \%$ & $16 \%$ & $14,20 \%$ \\
\hline
\end{tabular}

Source: internal survey of the Master Bank.

A higher level of NPLs (Table 5) increases the provisions towards the NBS and reduces the level of profitability. There are also certain write-offs that depend on the non-performing amounts which directly reduce the bank results. NPL also increases the standard risk costs (provisions) that reduce the CM1a margin. The subject cost includes the cost covered by healthy clients in order to compensate the losses of clients who went bankrupt or are transferred to NPL due to poor collection. On the other hand, CM3 margin is lower due to increased cost of capital which certainly increases as the level of clients in the NPLs is higher, i.e. the capital employed is exposed to greater risk through placement that brings a higher level of NPL. Also, it leads to the reduction of capital adequacy indicators as parameters of long-term financial stability, so it is necessary either to engage additional capital or make significant changes in loan granting policies.

4. The effective coverage of the total portfolio with collaterals

Table 6. The effective coverage of the total portfolio in \% (status with December of each fiscal year)

\begin{tabular}{|c|c|c|c|}
\hline 2011 & 2012 & 2013 & 2014 \\
\hline $53,33 \%$ & $43 \%$ & $55 \%$ & $35 \%$ \\
\hline
\end{tabular}

Source: internal survey of the Master Bank.

Larger coverage (Table 6) reduces the level of provisions towards the NBS, reducing the cost of capital employed, as well as the standard risk costs - 
Kasavica P., Jović Z.: Impact of asset quality on bank profitability - Case Study

provisions. Thus, a greater coverage increases the profits, as higher quality collaterals are indicators that influence the credit quality of a particular placement.

5. Effective coverage of NPL portfolio with collaterals

Table 7. The effective coverage of NPL portfolio in \% (status with December of each fiscal year)

\begin{tabular}{|c|c|c|c|}
\hline 2011 & 2012 & 2013 & 2014 \\
\hline $76,70 \%$ & $73,20 \%$ & $76 \%$ & $86,50 \%$ \\
\hline
\end{tabular}

Source: internal survey of the Master Bank.

Effective coverage of NPL (Table 7) has the same effect as the previous item 4 , but also represents a significant maneuver space for the eventual sale of the collateral coverage of NPLs. Thus, it leaves more room for potential "exit strategies".

Applying the above-described parameters of Master Bank micro segments, below given is the panel regression statistical model (fixed effect regression model) which further indicates the interdependence of the aforementioned categories.

\section{a) Descriptive indicators of the parameters}

Table 8. Micro segment asset side indicators

\begin{tabular}{|c|c|c|c|c|c|}
\hline Time & 2011 & 2012 & 2013 & 2014 & Total \\
\hline $\begin{array}{c}\text { Long } \\
\text { term }\end{array}$ & $28,832,540,000$ & $28,146,750,000$ & $24,830,650,000$ & $27,864,620,000$ & $27,418,640,000$ \\
\hline $\begin{array}{c}\text { Short } \\
\text { term }\end{array}$ & $2,747,460,000$ & $2,001,600,000$ & $3,361,430,000$ & $1,922,520,000$ & $2,508,252,500$ \\
\hline Rating A & $766,752,000,000$ & $833,405,000,000$ & $674,611,000,000$ & $720,026,000,000$ & $748,698,500,000$ \\
\hline $\begin{array}{c}\text { Rating } \\
\text { B-C }\end{array}$ & $134,950,000,000$ & $101,863,000,000$ & $78,881,000,000$ & $66,520,000,000$ & $95,553,500,000$ \\
\hline Rating 1 & 0 & 0 & 0 & $1,667,000,000$ & $416,750,000$ \\
\hline $\begin{array}{c}\text { Rating } \\
4-5\end{array}$ & $1,048,458,000,000$ & $1,105,781,000,000$ & $797,266,000,000$ & $955,091,000,000$ & $976,649,000,000$ \\
\hline $\begin{array}{c}\text { Rating } \\
6-7\end{array}$ & $582,240,000,000$ & $487,425,000,000$ & $444,797,000,000$ & $447,641,000,000$ & $490,525,750,000$ \\
\hline Rating 8 & $124,521,000,000$ & $134,839,000,000$ & $129,904,000,000$ & $100,256,000,000$ & $122,380,000,000$ \\
\hline Rating N & 0 & 0 & 0 & $88,625,000,000$ & $22,156,250,000$ \\
\hline Rating R & $582,171,000,000$ & $729,833,000,000$ & $699,407,000,000$ & $598,889,000,000$ & $652,575,000,000$ \\
\hline NPL (\%) & 154 & 117 & 160 & 142 & 143,25 \\
\hline $\begin{array}{c}\text { portfolio } \\
\text { cov. (\%) }\end{array}$ & 533,3 & 430 & 550 & 350 & 465,825 \\
\hline $\begin{array}{c}\text { NPL } \\
\text { cov. (\%) }\end{array}$ & 767 & 732 & 760 & 865 & 781 \\
\hline
\end{tabular}

Source: authors' survey based on Master bank data 
Kasavica P., Jović Z.: Impact of asset quality on bank profitability - Case Study

Table 9. The margins of profitability of Master Bank micro clients

\begin{tabular}{|c|c|c|c|c|}
\hline Time & CM1 assets & $\begin{array}{c}\text { CM1 margin } \\
\text { assets side (\%) }\end{array}$ & CM5 & CM5 margin (\%) \\
\hline 2011 & $1,441,250$ & 49,9 & 622,06 & 21,5 \\
\hline 2012 & $1,933,260$ & 69,2 & $4,340,000$ & 0,02 \\
\hline 2013 & $1,537,170$ & 58,7 & $1,370,590$ & 52,3 \\
\hline 2014 & $1,357,190$ & 58,5 & 736,11 & 31,7 \\
\hline Total & $1,567,218$ & 59,075 & $1,767,190$ & 26,425 \\
\hline
\end{tabular}

Source: authors' survey based on Master bank data

Aforementioned variables (Table 8 and 9) are numerical, and encompassed period is 4 years, 2011 - 2014. Tables show variables per presented years; therefore it is possible to identify their maximum and minimum values. Regarding asset side indicators it is visible that column total presents average values of referred parameters.

\section{a) The influence of parameters on dependent variables}

Table 10. The influence of portfolio maturity parameters

\begin{tabular}{|c|c|c|c|c|c|c|}
\hline $\begin{array}{l}\text { Dependent } \\
\text { variable }\end{array}$ & Predictors & Estimate & $\mathrm{p}$ & \multicolumn{2}{|c|}{ 95\% Confidence Interval } & $\begin{array}{c}\text { Information } \\
\text { Criteria }\end{array}$ \\
\hline \multirow{2}{*}{ CM1 assets } & $\begin{array}{l}\text { maturity - } \\
\text { long term }\end{array}$ & $5.39 \mathrm{E}+01$ & 0,027 & $1.02 \mathrm{E}+01$ & $9.75 E+01$ & \multirow{3}{*}{$\mathrm{BIC}=40,65$} \\
\hline & $\begin{array}{l}\text { maturity - } \\
\text { short term }\end{array}$ & $3.48 \mathrm{E}+01$ & 0,845 & $-0,00043$ & 0,0005 & \\
\hline \multirow{2}{*}{$\begin{array}{l}\text { CM1 margin } \\
\text { assets side } \\
(\%)\end{array}$} & $\begin{array}{l}\text { maturity - } \\
\text { long term }\end{array}$ & $2.13 \mathrm{E}+00$ & 0,017 & 6.37E-01 & $3.62 \mathrm{E}+00$ & \\
\hline & $\begin{array}{l}\text { maturity - } \\
\text { short term }\end{array}$ & 1.85E-01 & 0,976 & $-1.57 \mathrm{E}+01$ & $1.61 \mathrm{E}+01$ & $\mathrm{BIC}=13,65$ \\
\hline \multirow{2}{*}{ CM5 } & $\begin{array}{l}\text { maturity - } \\
\text { long term }\end{array}$ & 0,00012 & 0,289 & $-0,00015$ & 0,000392 & \multirow{2}{*}{$\mathrm{BIC}=55,30$} \\
\hline & $\begin{array}{l}\text { maturity - } \\
\text { short term }\end{array}$ & $-0,00061$ & 0,591 & $-0,00351$ & 0,00229 & \\
\hline \multirow{2}{*}{$\begin{array}{c}\text { CM5 margin } \\
(\%)\end{array}$} & $\begin{array}{l}\text { maturity - } \\
\text { long term }\end{array}$ & $-1.07 E+00$ & 0,281 & $-3.47 \mathrm{E}+00$ & $1.32 \mathrm{E}+00$ & \multirow{2}{*}{$\mathrm{BIC}=17,43$} \\
\hline & $\begin{array}{l}\text { maturity - } \\
\text { short term }\end{array}$ & $2.22 \mathrm{E}+01$ & 0,073 & $-3.32 E+00$ & $4.77 \mathrm{E}+01$ & \\
\hline
\end{tabular}

Source: authors' survey

Multivariate models have the advantage of numerical stability and accuracy of inference even on small samples. This is one of the reasons for the use of fixed effect regression model. The time period of four years was considered, throughout which the predictors were monitored. The table above (Table 10) 
Kasavica P., Jović Z.: Impact of asset quality on bank profitability - Case Study

presented the influence of the predictors on four dependent variables. The success of the model is monitored through Schwarz's Bayesian Criterion, where the absolute number shows the success of the model. The lower the number, the better the model.

Table 11. The influence of rating parameters and the amount of loans by rating

\begin{tabular}{|c|c|c|c|c|c|c|}
\hline $\begin{array}{l}\text { Dependent } \\
\text { variable }\end{array}$ & Predictors & Estimate & $p$ & 95\% Confic & ce Interval & $\begin{array}{c}\text { Information } \\
\text { Criteria }\end{array}$ \\
\hline \multirow{8}{*}{ CM1 assets } & A & $2.10 \mathrm{E}+00$ & 0 & $1.80 \mathrm{E}+00$ & $2.39 E+00$ & \multirow{9}{*}{$\mathrm{BIC}=33,45$} \\
\hline & B_C & $1.54 \mathrm{E}+01$ & 0,002 & $9.29 \mathrm{E}+00$ & $2.15 E+01$ & \\
\hline & $\overline{\mathrm{P} 1}$ & 0,000814 & 0,396 & $-0,00157$ & 0,003196 & \\
\hline & P4_5 & $1.59 \mathrm{E}+00$ & 0 & $1.29 \mathrm{E}+00$ & $1.89 E+00$ & \\
\hline & P6_7 & $3.15 E+00$ & 0 & $2.34 \mathrm{E}+00$ & $3.96 \mathrm{E}+00$ & \\
\hline & $\mathrm{P} 8$ & $1.28 \mathrm{E}+01$ & 0 & $1.11 \mathrm{E}+01$ & $1.45 \mathrm{E}+01$ & \\
\hline & $\mathrm{N}$ & $1.53 \mathrm{E}+01$ & 0,396 & $-2.95 \mathrm{E}+01$ & $6.01 \mathrm{E}+01$ & \\
\hline & $R$ & $2.41 \mathrm{E}+00$ & 0 & $2.14 \mathrm{E}+00$ & $2.67 E+00$ & \\
\hline \multirow{8}{*}{$\begin{array}{l}\text { CM1 margin } \\
\text { assets side } \\
(\%)\end{array}$} & A & 7.87E-02 & 0 & 6.72E-02 & 9.03E-02 & \\
\hline & B_C & $5.29 \mathrm{E}-01$ & 0,003 & $2.96 \mathrm{E}-01$ & 7.62E-01 & \multirow{7}{*}{$\mathrm{BIC}=6,35$} \\
\hline & P1 & $1.40 \mathrm{E}+01$ & 0,234 & $-1.38 \mathrm{E}+01$ & $4.17 \mathrm{E}+01$ & \\
\hline & P4_5 & 8.21E-02 & 0,111 & $-2.98 \mathrm{E}-02$ & 1.94E-01 & \\
\hline & P6_7 & $-4.46 \mathrm{E}-02$ & 0,608 & $-2.68 \mathrm{E}-01$ & $1.78 \mathrm{E}-01$ & \\
\hline & P8 & 4.58E-01 & 0 & 3.94E-01 & 5.22E-01 & \\
\hline & $\mathrm{N}$ & 1.42E-01 & 0,091 & $-3.56 \mathrm{E}-02$ & 3.19E-01 & \\
\hline & $\mathrm{R}$ & 9.05E-02 & 0 & $8.25 \mathrm{E}-02$ & 9.85E-02 & \\
\hline \multirow{8}{*}{ CM5 } & A & 1.09E-01 & 0 & 8.30E-02 & $1.35 \mathrm{E}-01$ & \multirow{8}{*}{$\mathrm{BIC}=6,47$} \\
\hline & B_C & $-2.35 E-01$ & 0,029 & $-4.31 \mathrm{E}-01$ & $-3.85 E-02$ & \\
\hline & P1 & $1.07 \mathrm{E}+00$ & 0,865 & $-1.53 \mathrm{E}+01$ & $1.74 \mathrm{E}+01$ & \\
\hline & P4_5 & 5.94E-02 & 0 & 4.55E-02 & 7.32E-02 & \\
\hline & P6_7 & $-1.76 \mathrm{E}-02$ & 0,776 & $-1.78 \mathrm{E}-01$ & 1.43E-01 & \\
\hline & P8 & 5.49E-01 & 0,077 & -9.34E-02 & $1.19 \mathrm{E}+00$ & \\
\hline & $\mathrm{N}$ & 6.11E-02 & 0,174 & $-4.17 \mathrm{E}-02$ & 1.64E-01 & \\
\hline & $\mathrm{R}$ & $8.86 \mathrm{E}-02$ & 0 & $8.17 \mathrm{E}-02$ & $9.56 \mathrm{E}-02$ & \\
\hline \multirow{9}{*}{$\begin{array}{c}\text { CM5 margin } \\
(\%)\end{array}$} & A & 5.99E-02 & 0,362 & -1.02E-01 & $2.22 \mathrm{E}-01$ & \multirow{8}{*}{$\mathrm{BIC}=21,14$} \\
\hline & B_C & $-2.09 \mathrm{E}-01$ & 0,661 & $-1.44 \mathrm{E}+00$ & $1.02 \mathrm{E}+00$ & \\
\hline & $\overline{\mathrm{P} 1}$ & $6.53 \mathrm{E}+00$ & 0,676 & $-3.38 \mathrm{E}+01$ & $4.69 \mathrm{E}+01$ & \\
\hline & P4_5 & $2.18 \mathrm{E}-02$ & 0,151 & $-1.24 \mathrm{E}-02$ & 5.60E-02 & \\
\hline & P6_7 & $-1.76 \mathrm{E}-02$ & 0,911 & $-4.30 \mathrm{E}-01$ & 3.95E-01 & \\
\hline & $\mathrm{P} \overline{8}$ & 2.79E-01 & 0,664 & $-1.38 \mathrm{E}+00$ & $1.93 E+00$ & \\
\hline & $\mathrm{N}$ & 1.13E-01 & 0,66 & $-5.49 \mathrm{E}-01$ & 7.76E-01 & \\
\hline & $\mathrm{R}$ & 3.62E-02 & 0,088 & -8.59E-03 & $8.10 \mathrm{E}-02$ & \\
\hline & $\begin{array}{l}\text { maturity - } \\
\text { short term }\end{array}$ & $2.22 \mathrm{E}+01$ & 0,073 & $-3.32 E+00$ & 4.77E+01 & \\
\hline
\end{tabular}

Source: authors' survey 
Kasavica P., Jović Z.: Impact of asset quality on bank profitability - Case Study

From the parameters of portfolio maturity, the first dependent variable CM1 assets are dominantly affected by the long-term maturity. This criterion variable affects the dependent variable CM1 margin assets side (\%). Therefore, increasing the maturity in a long run affects the increase in CM1 assets and CM1 margin assets side. Maturity has no influence on parameters CM5 and CM5 margin. As pointed out in the section that describes the influence of every analysed asset category on profitability, subject analysis proves that the increase in long-term exposure, although to a lesser extent from short-term loans, affects the increase in CM1 assets and CM1 margin assets side (\%). The concrete example indicates that the strongest positive impact comes from the long-term portfolio, which is in case of Master Bank dominantly present in about $90 \%$ of the total exposure. This dominance is the reason why even the smallest changes in long-term portfolio affect the profit to a greater extent than larger ones in short-term portfolio.

From the client rating parameters, the first dependent variable CM1 assets is affected by parameters: rating A, B_C, P4_5, P6_7, P8 and R. All parameters have a positive effect. The dependent variable $\overline{C M} 1$ margin assets side (\%) is affected by the predictors: rating A, B_C, P8 and R. These parameters also have a positive effect. On the other hand, the dependent variable CM5 is affected by predictors: rating A, B_C, P4_5 and R. They have a positive effect, too. None of the predictors showed statistically significant effect on the dependent variable CM5 margin (\%) (Table 11). The concrete analysis indicates that the greatest positive impact on $\mathrm{CM} 1$ have poorer internal ratings (in addition to external $A, B, C$, these are internal ratings $P 8$ and $R$ ) as they require higher interest rate calculated at the origination of transaction, while better internal ratings (in addition to external ratings $A, B, C$, these are internal ratings 4 and 5) have more influence on CM5 margin as they require lower cost of capital and provisioning with NBS.

Table 12. The influence of NPL parameters

\begin{tabular}{|c|c|c|c|c|c|c|}
\hline $\begin{array}{c}\text { Dependent } \\
\text { variable }\end{array}$ & Predictors & Estimate & $\mathrm{p}$ & \multicolumn{2}{|c|}{$95 \%$ Confidence Interval } & $\begin{array}{c}\text { Information } \\
\text { Criteria }\end{array}$ \\
\hline CM1 assets & NPL & $10,662,772$ & 0,001 & $7,048,729$ & $14,276,816$ & BIC $=40,35$ \\
\hline $\begin{array}{c}\text { CM1 margin } \\
\text { assets side } \\
(\%)\end{array}$ & NPL & 0,402554 & 0,001 & 0,278039 & 0,527068 & BIC $=16,18$ \\
\hline CM5 & NPL & $11,150,780$ & 0,128 & $-5,031,898$ & $27,333,459$ & BIC55,12 \\
\hline $\begin{array}{c}\text { CM5 margin } \\
(\%)\end{array}$ & NPL & 0,19483 & 0,025 & 0,039184 & 0,350476 & BIC $=17,96$ \\
\hline
\end{tabular}

Source: authors' survey

NPL loans affect the dependent variables: CM1 assets, CM1 margin assets side (\%) and CM5 margin (\%). The impact is positive and statistically 
Kasavica P., Jović Z.: Impact of asset quality on bank profitability - Case Study

significant at the 0.01 level for the first two dependent variables and 0.05 for the third dependent variable (Table 12). According to analysis NPL loans contrary to the expected positively impact CM5 and CM1 margin. The fact is that there is a restriction to analysis because of cyclical movement, i.e. growth and decline in exposure from year to year. On the other side, instead of absolute, percentage values were taken. Also, in certain years there has been an impact of artificially taken full provisions which were not present in subsequent periods. In addition, the example comprises values on 31st December of every year, but not average ones for the whole year. Therefore, the result is partly inadequate.

Table 13. The influence of the effective coverage parameters of the total portfolio

\begin{tabular}{|c|c|c|c|c|c|c|}
\hline $\begin{array}{c}\text { Dependent } \\
\text { variable }\end{array}$ & Predictors & Estimate & $\mathrm{p}$ & \multicolumn{2}{|c|}{$95 \%$ Confidence Interval } & $\begin{array}{c}\text { Information } \\
\text { Criteria }\end{array}$ \\
\hline CM1 assets & $\begin{array}{c}\text { portfolio eff. } \\
\text { coverage }\end{array}$ & $3,265,516$ & 0,001 & $2,245,306$ & $4,285,727$ & $\mathrm{BIC}=42,50$ \\
\hline $\begin{array}{c}\text { CM1 margin } \\
\text { assets side } \\
(\%)\end{array}$ & $\begin{array}{c}\text { portfolio eff. } \\
\text { coverage }\end{array}$ & 0,122025 & 0,001 & 0,079725 & 0,164325 & $\mathrm{BIC}=17,04$ \\
\hline CM5 & $\begin{array}{c}\text { portfolio eff. } \\
\text { coverage }\end{array}$ & $3,588,701$ & 0,1 & $-1,082,406$ & $8,259,809$ & $\mathrm{BIC}=54,68$ \\
\hline $\begin{array}{c}\text { CM5 margin } \\
(\%)\end{array}$ & $\begin{array}{c}\text { portfolio eff. } \\
\text { coverage }\end{array}$ & 0,057488 & 0,037 & 0,005652 & 0,109324 & $\mathrm{BIC}=18,67$ \\
\hline
\end{tabular}

Source: authors' survey

The Effective provision/coverage from the total portfolio affects the dependent: CM1 assets, CM1 margin assets side (\%) and CM5 margin (\%). Statistical significance level is 0.01 for the first two dependable variables and 0.05 for the third dependent variable (Table 13). The increase in effective coverage has positive impact, as higher quality collaterals are indicators that influence the credit quality of a particular placement. This suggests that analysis proves previously highlighted and theoretically determined relations between this parameter and profitability.

Criterion variable called effective coverage of the NPL portfolio also affects the $\mathrm{CM} 1$ assets, CM1 margin assets side (\%) and CM5 margin (\%). Statistical significance level is 0.01 for the first two dependable variables and 0.05 for the third dependent variable (Table 14). Like in previous case the increase in effective coverage of NPL portfolio has positive impact which suggests that analysis proves previously highlighted and theoretically determined relations between this parameter and profitability. 
Kasavica P., Jović Z.: Impact of asset quality on bank profitability - Case Study

Table 14. The influence of the effective coverage parameters of the NPL portfolio

\begin{tabular}{|c|c|c|c|c|c|c|}
\hline $\begin{array}{c}\text { Dependent } \\
\text { variable }\end{array}$ & Predictors & Estimate & $\mathrm{p}$ & \multicolumn{2}{|c|}{$95 \%$ Confidence Interval } & $\begin{array}{c}\text { Information } \\
\text { Criteria }\end{array}$ \\
\hline CM1 assets & $\begin{array}{c}\text { NPL eff. } \\
\text { coverage }\end{array}$ & $1,984,868$ & 0,001 & $1,447,184$ & $2,522,552$ & $\mathrm{BIC}=41,41$ \\
\hline $\begin{array}{c}\text { CM1 margin } \\
\text { assets side } \\
(\%)\end{array}$ & $\begin{array}{c}\text { NPL eff. } \\
\text { coverage }\end{array}$ & 0,075162 & 0 & 0,059645 & 0,090679 & $\mathrm{BIC}=13,05$ \\
\hline CM5 & $\begin{array}{c}\text { NPL eff. } \\
\text { coverage }\end{array}$ & $2,176,538$ & 0,098 & $-0,63329$ & $4,986,362$ & $\mathrm{BIC}=54,45$ \\
\hline $\begin{array}{c}\text { CM5 margin } \\
(\%)\end{array}$ & $\begin{array}{c}\text { NPL eff. } \\
\text { coverage }\end{array}$ & 0,034207 & 0,043 & 0,001793 & 0,066622 & $\mathrm{BIC}=18,94$ \\
\hline
\end{tabular}

Source: authors' survey

It must be noted that the analysis has some limitations due to the lack of data on average movement of the aforementioned indicators of assets and profitability throughout the whole year covered. This means that the alternating daily or at least monthly impact on specific profitability margins was not included. Therefore, there is no logical sequence in certain interdependencies. In other words, given the available parameters of Master Bank and presented explanations on how certain indicators affect profits, interdependence alone cannot be accurately mapped on the shown panel regression model. For example, for rating, maturity, and NPL, we emphasized the exposure of Master Bank at the end of the year, and in certain situations this exposure was not present in this average throughout the whole fiscal year. This also refers to a specific part of the portfolio that is for certain years transferred to R at end of the year. This is usually done so the next year can be entered with a clean portfolio and in order to submit full provisions. With this in mind, the impact which is present at the end of the year is not constant throughout the whole fiscal year.

\section{Conclusions}

In the research/case study on the impact of asset quality on the profitability of a commercial bank, the influence of the following categories of assets quality on profitability was analyzed: maturity of portfolio, client ratings, NPL loans, the effective coverage of the total portfolio with collaterals and effective coverage of NPL portfolio with collaterals.

It was found that maturity affects the profitability margins, primarily the CM1 margin, which is conditioned primarily by the fact that, as a rule, long-term loans on annual level dictate slightly lower interest rates, while short-term 
Kasavica P., Jović Z.: Impact of asset quality on bank profitability - Case Study

loans dictate a slightly higher interest rate. In contrast, long-term resources are more expensive, which in general reduces the profit margin within the relationship between interest-source. Also, the fee for processing the loan application is split evenly by periods of the arrangement duration, which for long-term loans, as opposed to short-term, reduces the fee that is accounted in a particular year. This reduces the CM2 margin, but on the other hand, long-term loan arrangements are accompanied by mandatory additional products, and this affects the increase in fees during the year. Qualitatively speaking, the subject long-term loans as a rule have a greater degree of effective provision/coverage, clients have better ratings, there is participation of the client in risk of the transactions, etc., which definitely affects a certain reduction of provisions towards NBS (CM5), i.e. better rank of credit quality. On the other hand, the cost of capital according to the quality of the arrangement (CM3) is also lower. However, due to greater participation of other sectors in the bank in the analysis, as well as in the loan documents creation, the cost of the product increases.

As for the client rating, lower rating carries a higher cost, therefore a higher level of loans under less favorable rating costs more and reduces profits.

A higher level of NPLs increases the provisions towards the NBS and reduces the level of profitability.

For effective coverage of the total portfolio with collaterals, it is evident that a greater coverage reduces the level of provisions towards the NBS, reducing the cost of capital employed, as well as standard risk costs - provisions, which means that greater coverage increases profits.

Effective coverage of NPL portfolio with collaterals gives significant room for maneuver for the eventual sale of the collateral coverage of NPLs, which at the same time leaves more space for potential "exit strategy".

This research confirmed theoretical assumptions and set hypotheses, and provided specific practical tools for calculating the parameters of asset quality and their impact on the profitability of a commercial bank. This can also be applied on other commercial banks or a whole segment of banks similar in size and located in the same market, which would allow comparability of results. The proposed combination of modern methods for the assessment of banks' profitability and statistical methods for verifying the reasoning accuracy opens the door to further research in this area. 
Kasavica P., Jović Z.: Impact of asset quality on bank profitability - Case Study

\section{References}

Angbazo, L. (1997). Commercial bank net interest margins, default risk, interest rate risk, and off - balance sheet banking. Journal of Banking and Finance, vol. 21 , issue 1 , pages $55-87$.

Bodla, B. S., \& Verma, R. (2007). Determinants of profitability of banks in India: a multivariate analysis, Journal of Services Research 7.1 (Apr-Sep 2007): 7582,85-89.

Cass Business School, City University. (2012). Capital and profitability in banking: Evidence from US banks, London: Osborne, M., Fuertes A.-M., \& Milne A

Ćirović, M. (2007). Bankarstvo, Naučno društvo Srbije, Beograd.

EBA. (2013). Implementing Technical Standards on supervisory reporting of forbearance and non-performing exposures under article 99(4) of Regulation (UE) 575/2013 [EBA/ITS/2013/03]. Brussels.

ECB. (2013). Non-performing loans - What matters in addition to the economic cycle? (No.1515). Frankfurt am Main.

Ezeoha, A. (2011). "Banking consolidation, credit crisis and asset quality in a fragile banking system: Some evidence from Nigerian data", Journal of Financial Regulation and Compliance, Vol. 19 Iss: 1, pp.33 - 44

Gallo, J., Apilado, V., \& Kolari, J. (1996). Commercial bank mutual fund activities: Implications for bank risk and profitability, Journal of Banking \& Finance, Volume 20, Issue 10, December 1996, Pages 1775-1791.

Hou, Y., \& Dickinson, D. (2007, August). The non-performing loans: some bank- level evidences. Paper presented at the 4th International Conference on Applied Financial Economics, Samos Island, Greece.

IMF Working Papers. (2010). Nonperforming loans in the GCC banking system and their macroeconomic effects. IMF Working Papers, 1-24: Espinoza, R.A., \& Prasad, A.

IMF Working Paper. (2103). Non-Performing Loans in CESEE: Determinants and Impact on Macroeconomic Performance, European Department, WP/13/72, March 2013: Klein, N.

International Monetary Fund. (2015). What determines the profitability of banks? Evidence from Spain, Global Financial Stability Report: Bank nonperforming loans to total gross loans (\%):Trujillo - Ponce, A.

Jolevska, E., \& Andovski, I. (2015). Non-Performing Loans in the Banking Systems of Serbia, Croatia and Macedonia: Comparative Analysis (March 23, 2015). Ekonomika, Vol 61, Issue 1, pp 115-130, 2015. Available at SSRN: http://ssrn.com/abstract=2584122

Louzis, D., Vouldis, A. \& Metaxas, V. (2010). Macroeconomic and bank-specific determinants of non-performing loans in Greece: A comparative study of mortgage, business and consumer loan portfolios, Journal of Banking \& Finance, Elsevier, vol. 36(4), pages 1012-1027.

Miller, R., VanHose, D. (1993). Modern Money and Banking, McGraw-Hill, Inc.

Mishkin, F. (2004). The Economics of Money, Banking, and Financial Markets, Pearson Education, Inc.,

Rose, P. (1999). Commercial Bank Management, The McGraw-Hill Companies, Inc., 
Kasavica P., Jović Z.: Impact of asset quality on bank profitability - Case Study

Scott, J., \& Arias, J.C. (2011). Banking profitability determinants, Business Intelligence Journal - July, 2011 Vol.4 No.2.

Swamy, V. (2015). Modelling Bank Asset Quality and Profitability: An Empirical Assessment. Economics Discussion Papers, No 2015-27, Kiel Institute for the World Economy. $\quad$ http://www.economicsejournal.org/economics/discussionpapers/2015-27

Vuković, V., \& Domazet, I. (2013). Non-performing Loans and Systemic Risk: Comparative Analysis of Serbia and Countries in Transition CESEE, Industrija Journal, 41(4), 59-73. doi:10.5937/industrija41-4276

Miljković, M., Filipović, S., \& Tanasković, S. (2013). Profitability of Serbian Banking Sector During Global Economic Crisis, Industrija Journal, 41(4), 39-57. doi:10.5937/industrija41-5096 